\title{
Din istoricul pronumelui nehotărît altcineva. Contribuții gramaticale
}

\author{
Adrian Chircu* \\ Facultatea de Litere, Universitatea „Babeș-Bolyai,, Str. Horea 31, 400202 Cluj-Napoca, România
}

\section{Despre articol}

Istoric:

Primit 19 decembrie 2017

Acceptat 17 ianuarie 2018

Publicat 27 aprilie 2018

Cuvinte-cheie:

gramatică diacronică

sintagmă

lexicalizare

dinamică sintactică

pronume nehotărîte

cuantificatori

\begin{abstract}
Rezumat
În prezentul studiu, ne propunem să urmărim modul în care s-a constituit pronumele nehotărît altcineva în limba română. Faptele de ordin lingvistic sînt discutate, în mare măsură, în perspectivă diacronică, cea care ne poate ajuta să înțelegem care au fost etapele evolutive ale acestui pronume compus, pornindu-se de la o sintagmatizare după model latinesc și ajungîndu-se la o lexicalizare pe teren românesc. Pentru o analiză obiectivă și actuală, am prioritizat direcțiile investigative din recentele gramatici ale limbii române fie ele diacronice (Frâncu, 2009, Stan, 2013; SOR) ori sincronice (GALR; GBLR; RGR; GR).

În sprijinul acestui demers, am făcut apel la un număr reprezentativ de scrieri vechi (în principal din veacurile al XVI-lea şi al XVII-lea), care ilustrează dinamica limbii de odinioară, ca, de altfel, și mutațiile care au survenit pe parcurs. Cercetarea noastră a dus la rezultate interesante și inedite à la fois, referitoare la particularitățile structurale, la compatibilitatea semantică, la asocierea sintagmatică ori la implicațiile sintactice ale pronumelui în chestiune.
\end{abstract}

\section{Preliminarii}

În ultimul deceniu, în lingvistica românească, au apărut unele schimbări în ceea ce privește interpretarea morfosintactică, în sensul că centrul de interes nu-l mai reprezintă exclusiv descrierea părţilor de vorbire și a relaţiilor dintre ele în sincronie, ci acesta s-a deplasat înspre abordarea faptelor de limbă din perspectivă diacronică, singura care poate facilita înțelegerea adecvată a formării și a funcționării, în cadrul sistemului, a anumitor unități lexicale ori a unor structuri gramaticale particulare, prezente încă de la început sau apărute ulterior în limba română, în urma unor evoluții sinuoase.

1.1. În afara verbului, dintre clasele morfologice, cea mai complexă, dar și cea mai interesantă, rămîne cea a pronumelui, care are un inventar bogat și eterogen de unități constitutive, ce au cunoscut, de-a lungul veacurilor, întrebuințări variate și, uneori, limitate. Niculescu (1965) precizează că „particularitățile flexiunii pronominale în limba română constau nu atît în existența sau în nonexistența unui element, cît mai ales într-o utilizare deosebită a inventarului de forme moștenit din latină, precum și în valoarea funcțională atribuită fiecărui element în ansamblul sistemului” (p. 39).

1.2. Dintre categoriile de pronume, se detașează cea a indefinitelor ai cărei membri s-au format în număr semnificativ pe tărîmul limbii române, odată cu necesitățile evidente de a completa atît pierderile de la latină înspre română, cît și din nevoia de nuanțare a semnificațiilor (Stoica, 2011, p. 445). În acest sens, lingviștii care s-au aplecat pe îndelete asupra viețuirii unor pronume latinești ori asupra apariției altora în limba română au remarcat că „pronumele şi adjectivele nehotărîte prezintă mai multe particularități și neregularități datorită faptului că ele constituie o clasă mai eterogenă decît alte pronume" (Gheție, 1997, p. 129) și că se caracterizează prin anumite instabilități (Frâncu, 2009, p. 286). În paginile soR, G. Pană Dindelegan și colaboratorii săi observă că, în ceea ce privește cuantificatorii, „the specific features of $\mathrm{OR}^{1}$

*Adresă de corespondență: adrianchircu@yahoo.fr.

${ }^{1}$ Old Romanian. 
Adrian Chircu

quantified nominal phrases involve the inventory, form, word order, and values of quantifiers and the formal marking of the agreement between quantifiers and nouns" (sor, p. 356).

1.3. În această ipostază a complexității formale și a comportamentului sintactic se găsește și cuantificatorul indefinit altcineva, care, de-a lungul vremii, a cunoscut o evoluție interesantă, nerelevată pînă în prezent şi asupra căreia ne oprim în rîndurile ce vor urma, încercînd să ilustrăm, în special, particularitățile structurale și funcționale.

\section{Pronumele alter şi qui dinspre latină înspre română și înspre celelalte limbi romanice}

În ceea ce privește termenii constitutivi ai compusului altcine(va), aceștia sînt de origine latinească și sînt prezenți, în bună măsură, în întreaga Romanie.

2.1. De pildă, Wilhem Meyer-Lübke înregistrează, în coloanele dicționarului său (REW 382), următorii descendenți ai lat. ALTER: rom. alt, dalm. yultro, it. altro, sard. log. atteru, engad. oter, friul. altri, fr. prov. autre, cat. altre, sp. otro, port. outro, la care se adaugă alte forme, adesea vechi ori dialectale, nesemnalate de către lingvistul amintit: v. cat. altro, cat. dial. (Perpignan) altru, cors. altru, sard. campid. atru (àturu, àteru), sard. gal. altu, dalm. jualtro, prov. aurre, autre, galic. outro, astur. oitre, utru, calab. àutru (àvtru, atru), gasc. àut (áute, àude), v. leon. rioj. arag. nav. otre.

2.2. Aceeași răspîndire generală cunoaște lat. QUI (REW 6953), ale cărui forme sînt însă diferit repartizate (Väänänen, 2006, p. 126): pe de o parte, avem o selectare a formei-tip de nominativ (it. chi, v. sard. $\log$. $k i$, engad. $k i$, fr. prov. cat, v. sp., v. port. qui), iar, pe de altă parte, a formei de acuzativ quem, reperabilă în rom. cine, v. sard. log. ken, sard. campid. kini, surs. kuin, cat. (Mallorca) kin, sp. quien, port. quem, dalm. abruz. kẹnungẹ, galic. quen.

Privitor la acest din urmă constituent, respectiv cine, se poate observa că limba română concordă, în mare parte, cu domeniul lingvistic ibero-roman, susținîndu-se, și în acest caz, teoria ariilor laterale avansată de către Bartoli (1925) și adoptată și de către Pușcariu (1976, p. 212), întrucît descendenții pronumelui interogativ-relativ qui au o formă de acuzativ, faţă de limbile romanice centrale, în care avem forme pronominale ce descind dintr-un nominativ.

2.3. Pe tărîmul limbii române, la cel de-al doilea element al compusului, mai precis la cine (Densusianu, 1962, II, p. 125), s-a adăugat particula indefinită - va, a cărei origine trebuie căutată în paradigma formelor verbale ale verbului $a$ vrea (-va < vare < voare < lat. vOLET; Lombard, 1938, p. 203-205; Stoica, 2011, p. 446) și care are întrebuințări multiple la nivel morfologic. Această valoare complementară a verbelor care semnifică 'a vrea' nu este întîlnită exclusiv în română, ci și în alte limbi (Haspelmath, 1997, p. 159)2.

Rolul particulei este de a marca o nuanță de incertitudine $e^{3}$ în privința cunoașterii unei persoane (cineva, careva), a unui obiect (ceva), a unei circumstanțe (undeva, cumva, cîndva) ori a unei cantități (cîtva). Așadar, $-v a$ („scalar focus particule”) trebuie considerată o marcă a unor tipuri speciale de pronume indefinite sau adverbe, sugerînd indeterminarea (Haspelmath, 1997, p. 158).

În timp, noii forme compuse i s-a alipit, precum altor membri ai clasei pronominale, particula şi, care provine din lat. IPSE (Dimitrescu, 1974, p. 154) și care a cunoscut, în partea orientală a Imperiului Roman, o întrebuințare semnificativă, marcînd adesea insistența.

2.4. Sintagme asemănătoare din punct de vedere formal și/sau funcțional întîlnim nu numai în latină (qui alter), ci și în limbile romanice din domeniile lingvistice galo-italice (it. qui altro, altro qualcun, qualcun

\footnotetext{
${ }^{2}$ Lombard (1938, p. 204) menționează că există o particulă asemănătoare în albaneză (do), de origine verbală (vb. dua 'a iubi, a-i plăcea, a vrea, a voi, a dori ceva'). Aceasta se atașează unor pronume nehotărîte (kush-dó, tsíli-dó, sikush-do, sitsili-do etc.).

${ }^{3}$ Manoliu Manea (1968, p. 111) consideră că -va este un indice al nondelimitării și că ,joacă rolul de determinativ explicit al seriei cine, ce" și că nu este exlus să apară și determinări explicite (cineva dintre noi).
} 
altro; fr. qui (d') autre, quelqu'un d'autre; cors. chi altru etc. $)^{4}$. Din contră, de-a lungul secolelor, în teritoriile ibero-romanice, s-a răspîndit o sintagmă (qui magis) ce diferă din punct de vedere structural, însă nu și funcțional (sp. quién más, port. quem mais, cat. qui més, galic. quen máis etc.). Aceste exemple dovedesc că avem de-a face cu o trăsătură sintactică moștenită, însă care, ulterior, a cunoscut o oarecare detaşare de modelul inițial.

2.5. În sprijinul celor anterior prezentate, pot fi aduse în discuție și remarcile făcute de către Le Goffic (2015) asupra relațiilor care se stabilesc între pronumele interogative și cele nehotărîte. Acesta afirmă că, în astfel de situații, avem a face atît cu asemănări, cît și deosebiri; în privința similitudinilor, avem introducerea unei variabile care deschide multiple căi de abordare (întrebare, indefinire, subordonare etc.), reperabile în orice limbă; referitor la deosebiri, acestea rezidă în funcționare și în evoluție. De asemenea, în perspectivă diacronică, clasa interogativelor este stabilă, însă pronumele nehotărîte sînt „extrêmement instables, ils constituent des séries paradigmatiques aux contours souvent flottants ou incertains, souvent en relation de chevauchement partiel et/ou de concurrence" (Le Goffic (2015), p. 132).

\section{Repere teoretice actuale asupra cuantificatorilor constitutivi}

Pentru o interpretare adecvată a asocierii sintagmatice a celor doi cuantificatori (altul + cineva), considerăm că ar trebui să urmărim dacă pot fi identificați anumiți factori de ordin semantico-funcțional, care ar fi putut duce la lexicalizarea sintagmei autonome $e^{5}$. După cum se poate remarca, gruparea este alcătuită din doi cuantificatori existențiali, situație care a facilitat, într-un anumit fel, apropierea lor în cadrul structurii investigate, în ciuda unor trăsături semantice diferite.

3.1. Pe de o parte, alt(ul) este un separativ [+ Separativ] și are următoarele trăsături semantice: [- Aproximare], [+ Relativ], [+ Unic], [- Legat discursiv], [ \pm Uman], iar, pe de altă parte, cineva cunoaște următoarele opoziții lexicalizate $^{6}$ : [-Separativ], [- Aproximare], [- Relativ], [- Unic], caracterizat fiind și prin apreciere calitativă [- Legat discursiv], [+ Uman], [- Spec.] (GALR, I, p. 256).

3.2. De asemenea, trebuie menționat faptul că amîndoi termenii antrenați în constituirea sintagmei conțin „semantic ideea (presupoziția) de existență a unor elemente (elementele cuantificate)” (GBLR, p. 144), asocierea nefiind întîmplătoare, căci atît cineva, cît și altul nu aduc o informație suplimentară în enunț în ceea ce privește persoana la care se raportează. De fapt, altul nu face altceva decît să opereze o selecție succesivă: nu cineva, ci altcineva, o altă persoană decît cea iniţial desemnată.

3.3. În paginile GR, alternativul altul este descris din aceeași perspectivă, considerîndu-se că este un indefinit care are o dublă categorizare, lexicală și funcțională și că, în cazul elipsei nominale, ,assumes a special form (incorporating the bound-morpheme definite article)" (p. 300).

3.4. Se poate observa că termenii antrenați în constituirea sintagmei iniţiale au valori diferite, singura trăsătură care îi unește fiind [- Aproximare]. De altfel, în cadrul opoziției [+ Relativ] / [- Relativ], entitățile din domeniul cuantificat pot fi privite în sine (unul, cineva) sau prin raportare la alte entități din domeniul cuantificat, față de care se diferențiază sub anumite aspecte (altul, altcineva)" (GALR, I, p. 255).

3.5. Din analiza semică a acestor cuantificatori existențiali, reiese că anumite incompatibilități de ordin semantic s-au șters ori s-au atenuat, ceea ce a facilitat, de altfel, și crearea compusului altcineva.

\footnotetext{
${ }^{4}$ Pentru unele detalii privitoare la acest tip de sintagme din limbile romanice, a se vedea și Avram (2005, p. 162-167).

${ }^{5}$ Prévost \& Fagard (2007, p. 6) consideră că ,la lexicalisation tend à mettre l'accent sur la forme d'arrivée, lexicale, et accorde [...] une importance moindre aux mécanismes à l’œuvre, même si, parmi eux, la coalescence est souvent considérée comme décisive".

${ }^{6}$ A se vedea, de asemenea, Manoliu Manea (1968, p. 109-113).
} 


\section{Altcineva: dinspre sintagmatizare înspre lexicalizare în limba veche}

În principalele lucrări de gramatică istorică românească, procesul evolutiv al compuselor nehotărîte este urmărit secvențial, autorii limitîndu-se, în principal, la descrierea inventarului și la relevarea în special a unor trăsături generale ale clasei (Avram, 2005, p. 162-167; Popescu-Marin, 2007, p. 254-256) și, mai puțin, la comportamentul sintactic al acestora, fie că este vorba despre un centru de grup sau despre un adjunct.

4.1. De pildă, Stan (2013) constată că ,anumite tipuri de combinații între cuantificatori și determinanții pronominali au ieșit din uz în epoca veche” și precizează că „,anumite variante de topică a cuantificatorilor în raport cu determinanţii pronominali nu s-au impus în limbă (alte multe fi-vor, GS, 27v, p. 318)” (p. 54), iar G. Pană Dindelegan et al. susțin că ,at the beginning of the old period, the constraints of the distribution definite/non-definite forms of determiners alt(ul) were not fixed. Thus, in structures with overt nominal heads, there appear not only article-less forms, which generalized as adjectives (altă țară, Dî, 33, $241^{\mathrm{v}}$, p. 130), but also definite forms (altul oarecarele giurämîntu, CV, 67 , p. 362), which specialized as pronouns; in the structures in which the determiner is used pronominally, the adjectival form is also available (va face curvie una cu altă, Prav.1581, 205 $-206^{\mathrm{r}}$, p. 162)" (soR, p. 303).

4.2. Studiul atent al scrierilor noastre vechi ilustrează că, în ceea ce privește apariția cuantificatorului asupra căruia ne aplecăm în acest studiu (altcineva), avem de-a face cu un proces complex, de durată, în cadrul căruia s-au petrecut modificări esențiale.

Probabil că, înainte de constituirea sintagmei în discuție, procesul de asociere dintre cine și particula -va era pe cale de a se fi încheiat, după cum lasă să se înțeleagă atestările din veacul al XVI-lea ${ }^{7}$. Prin constituirea lui cineva și a altor cuantificatori similari, se reface, într-un anumit fel, o parte din complexul sistem pronominal latinesc, care a suferit pierderi importante. De pildă, în limba română, nu găsim nici o urmă a lat. aliquis, aliqua, aliquid, aliquod; quispiam, quapiam, quidpiam; qui, que, quod; quidam, quedam, quoddam; quis (que), quid (quod); quisquam, quequam, quodquam (quidquam).

4.3. Așadar, forma compusă (altcineva) este rezultatul contopirii elementelor sale componente și își găsește o explicație în faptul că cineva avea înțelesul 'o persoană oarecare; o persoană pe care nu o cunoaștem', iar, pentru a desemna o altă persoană necunoscută, avea nevoie de un determinant care să-i clarifice semnificația. Astfel, prin intermediul indefinitului altul, se ivește posibilitatea de a desemna o altă persoană oarecare; o altă persoană necunoscută sau căreia nu vrem să-i dezvăluim / să-i precizăm identitatea (Altcineva a fost acolo, nu el).

4.4. Compusul altcineva este atestat încă din secolul al XVI-lea atît în scrieri ce au un caracter religios, cît și în scrieri laice ${ }^{8}$, însă nu cu o frecvență ridicată, ci apare doar sporadic, ceea ce sugerează faptul că încă nu se generalizase întrebuințarea sa:

(1) E să Ilie și Pavel sau altu-cineva cătră ceriu s-au fost luați (cC² $\left.{ }^{2}, 515, \mathrm{p} .461\right)$

(2) n-au avut, nice de la Aron vodă, nice de la altucineva (Dî, 58, 2 ${ }^{\mathrm{r}}$, p. 180)

4.5. De asemenea, se poate observa că puținele ocurențe dovedesc că altcineva nu se stabilizase încă din punct de vedere formal, ezitările apărînd chiar în interiorul aceluiași text și, în special, în situațiile în care aveam cazurile dativ şi genitiv:

(3) nu altui cuiva, dentr-acela adeveritu, spre una de eluşu (CC² 459 , p. 409)

\footnotetext{
${ }^{7}$ Avram (2005, p. 163) observă că, în limba română, avem „o serie de compuse mai complexe, cu alt + un compus nehotărît cu bază relativă”.

${ }^{8}$ Pentru identificarea exemplelor, am parcurs un număr însemnat de texte, inclusiv crestomații (de pildă, CLRV sau LRM), însă, în Corpus, le-am inclus doar pe cele care conțineau fapte de limbă relevante pentru demersul nostru investigativ. Textele aparțin în esență unor arii stilistice diferite (texte religioase, administrative ori literare), fiind vorba atît despre traduceri, cît și despre scrieri originale.
} 
4.6. În următoarele două veacuri, forma pronominală începe să se fixeze și să se răspîndească, însă totuși am identificat ezitări de folosire în texte reprezentative din secolul al XVII-lea, mai ales la cazurile oblice, care ridică, după cum se va vedea, probleme de acord intrasintagmatic. Se poate constata că, la cazurile oblice (6-10), autonomia elementelor constitutive este mai ușor de reperat decît la cele directe (4-5):

(4) de la stăpăniri sau de la alt cineva a tocmi moara (SD, p. 301)

(5) Nu sămt eu Dumnedzău nice altul cineva de noi (CazV., 77v, p. 378)

(6) Un om de va vrea să lase altuicuiva vreun lucru (Prav.1646, p. 75)

(7) din partea altcuiva dintre acei, care au o apreciabilă experiență (AI,O, p. 401)

(8) acela face prepus cum să dea altuicuiva să se otrăvească (Prav.1652, p. 244)

(9) iară nu cu altă eparbie a altuicuiva (Prav.1652, p. 400)

(10) iară nu altuicuiva, că cătră tine grăiaște (Ê̂, 262, p. 300)

În aceste exemple, se observă că, adesea, avem sintagme alcătuite din termeni ce se caracterizează prin independență morfologică și prin dependență sintactică. Cu timpul însă, forma cuantificatorului pronominal altul va cunoaște un proces evolutiv care are drept rezultat apropierea formală de adjectiv (alt), iar nu funcțională (alt are valoarea lui altul). Chiar dacă, în anumite situații (1-2), -l lipsește (altu), informația gramaticală sugerată de acesta este preluată, întocmai ca la numele comune din limba vorbită, de desinența $u$ (GBLR, p. 89), care, precum formantul complet - ul, diferențiază pronumele de adjective (GBLR, p. 147) și le încadrează pe cele dintîi la tipul 1, unde „opozițiile gramaticale se marchează prin desinențe care exprimă solidar genul, numărul și cazul” (GALR, I, p. 262). La cazurile oblice, se remarcă omisiunea aproape generală a particulei pronominale $-a$, în structura cuantificatorului existențial altul (în loc de altuia, avem altui).

4.7. Situațiile în care elementul constitutiv principal al sintagmei (cineva) este însoțit de particula -și (cinevași/cinevaş) au o frecvență relativ scăzută, însă sînt relevante pentru urmărirea aspectelor legate de apariția formei compuse ce ne interesează. În asemenea contexte, rolul lui $(-s ̦ i)$ nu este doar de marcare a clasei pronominale, ci și de întărire a părții de vorbire din a cărei structură face parte. Se observă, din nou, că, la cazurile oblice, autonomia lui cinevaşi este mult mai evidentă, probabil și din cauză că forma nehotărîtului este simțită greoaie, mai ales că are în structura sa un număr de patru constituenți ${ }^{9}$ :

(11) ce ca cînd ară munci pre alt cinevaş, așa să ne pare noao ( $\left.\mathrm{CC}^{2}, 66, \mathrm{p} .68\right)$

(12) nici că zice altcinevași fără numai acest Pătrașcu țiganu (AJ, 845, p. 921)

(13) dîndu-i altcinevași banii, să fie volnic a da casile (AJ, 531, p. 590)

(14) nici le-au dat altui cuivași danie, ci au rămas dă a să stăpîni (AJ, 408, p. 452)

(15) vreo bănuială asupra Dinului Căprescul sau a altui cuivași (AJ, 682, p. 641)

(16) că nu scrie în diiată că-l lasă Lipoveanului sau altui cuivaşi (AJ, 518, p. 576)

4.8. Interesant ne apare și exemplul următor, în care avem o asociere între o formă de plural a alternativului (altor) cu nehotărîtul cinevași, care are o formă de singular, însă i se atribuie un înțeles de plural. Probabil că avem de face cu o structură analogică, în care se pornește de la folosirea formei primare cine cu înțeles de plural. Dimitrescu (1974, p. 184) identifică mai multe scrieri în care apare această valoare, precizînd că cine era folosit și pentru singular, și pentru plural (cine mă văzură, $\mathrm{CP}^{1}, 51^{\mathrm{r}}$, p. 135 / cire iubiți Zeul, ps, $159^{r}$, p. 201), întrebuințare care nu este reperată în limba română actuală:

(17) ei vrea să margă asupra altor cuivaş (CC,IȚR, $\left.71^{\mathrm{r}}, \mathrm{p} .193\right)$

4.9. Determinările grupării nu sînt frecvente, adjuncții avînd valoare adjectivală sau pronominală. În astfel de cazuri, centrul de grup este reprezentat de amîndoi membrii constitutivi (altul + cineva) sau, implicit, de forma compusă (altcineva):

\footnotetext{
${ }^{9}$ Fără a oferi exemple extrase din texte vechi, Avram (2005, p. 163) menţionează și o formă supracompusă cu cinci membri (vrealtcineva).
} 
(18) in pilda a altui cuiva păcătos ca-ntr-o oglindă a o privi poate (CD, p. 139)

(19) sau pre altcineva oarecarele vei tu (Mărg., $153^{\mathrm{r}}$, p. 426)

(20) veri altcineva a lui, să nu hulească pre Dumnezeu (Mărg., 147 , p. 410)

4.10. Într-un singur enunț reperat de noi, compusul altcineva este folosit cu valoare adjectivală. Utillizarea este atipică, deoarece pronumele compuse cu cine nu cunosc această valoare. Presupunem că avem de-a face cu o schimbare de valoare gramaticală datorată confuziei cu un cuantificator existențial de aceeași factură, respectiv altul, mult mai des întrebuințat și cu valori mult mai generale [ \pm uman] și, adesea, compatibile cu cele ale lui altcineva [+ uman], care este unul dintre corespondenții săi nonseparativi (GALR, I, p. 258):

(21) de-l va lua altul cineva om de a besearicii ${ }^{10}$ (DVs, $214^{\mathrm{r}}$, p. 189)

4.11. Aceeaşi compatibilitate funcțională poate fi remarcată și în situațiile în care nimeni este asociat, în cadrul unor sintagme, cu altul sau altcineva (Chircu, 2014, p. 53-67), negativul substituind ,substantivele de «gen personal», ca și nume de alte animate sau de inanimate personificate, aparținînd, din punct de vedere semantic, paradigmei în care se încadrează și pronumele relativ-interogativ cine(?) și pronumele nehotărîte cineva, oricine" (Dominte, 2003, p. 72):

(22) nimini altcinevași să nu să amestece făr' dă numai vătafu (AJ, 177, p. 193)

(23) den vreme că nime altul n-au știut acia taină, fără numai hatmanul (CAM, 31 1, p. 146)

(24) nu easte altul nimenea färă mine (CPop. ${ }^{3}, 43^{\mathrm{r}}$, p. 215)

(25) nimănui altuia ca mie, nu iaste vestit șî mărturisit a o ispiti (vI, 204v , p. 233)

4.12. În exemplul de mai jos, se poate observa totuși că, între cele două alternative (altul și altcineva), se simțea o diferență de semnificație, din moment ce sînt întrebuințate în acelaşi enunț ('pe tine, pe altul sau pe o cu totul altă persoană neprecizată):

(26) cînd vei vedea pre tine, sau pre altul, sau den slugile tale, sau din coconii tăi, sau pre altcineva din casa ta că să jură adease (Marg, 1691,73․, p. 218)

4.13. Se pare că, în unele zone, la începutul veacului al XIX-lea, elementele constitutive ale lui altcineva își păstrau încă independența, ceea sugerează că pronumele erau încă considerate două elemente diferite, cu autonomie gramaticală:

(27) poate el încredinţa vînzarea lor altuia cuiva (AB, 6, p. 192)

4.14. Ca o reminiscență a structurii latinești qui alter, s-a păstrat în română o structură arhaică cine alt(ul) / alt(ul) cine, prezentă, în general, în enunțuri interogative ${ }^{11}$, care are un corespondent în limba italiană (chi altro) și care a fost concurată tot mai mult de forma pronominală compusă (altcineva):

(28) Cine altul va răsî̀i sêmnele grăitorilor din pîntece...? (MVTs, 25, p. 559)

(29) Cine alt va zice ție aceastea care-ț zic eu? (Mărg., 16 ${ }^{\mathrm{r}}, 63$ )

\footnotetext{
${ }^{10}$ Sintagma este ușor ambiguă, putînd fi interpretată și ca o apoziție (de-l va lua altul cineva [,] om de a besearicii).

${ }^{11}$ A se vedea supra, discuțiile de sub $\$ 2.5$.
} 


\section{Interpretarea morfosintactică a lui altcineva}

Morfosintaxa compusului investigat nu a fost îndeajuns studiată din perspectivă diacronică, în ciuda faptului că pot fi reperate o serie de particularități structurale, cum ar fi flexiunea dublu marcată-pe de o parte, la primul element constitutiv, iar, pe de altă parte, la cel de-al doilea—sau absența formanților pronominali.

5.1. Dintru început, ținem să precizăm că structurile din limba veche contrazic descrierea comportamentului morfosintactic al nehotărîtului altcineva, realizată de către Giurgea (2010) pentru stadiul actual al limbii. Acesta susține că, în româna contemporană, cuantificatorul existențial cineva formează împreună cu altul anumite pronume compuse care sînt percepute ca niște entităţi sintactice simple și că „l'analyse de ces formes comme des composés (au lieu de alt ceva 'autre quelque chose', alt + NP ?) est soutenue par la flexion casuelle; tandis que alt prénominal reçoit des désinences casuelles (pour le genre et le nombre, on peut toujours dire que ceva et cineva ne sont que des masculins singuliers), les formes altcineva et altceva ne présentent que la flexion casuelle qui caractérise la deuxième partie: oblique altcuiva comme cuiva à/de quelqu'un', absence d'une forme oblique pour altceva comme pour ceva (Giurgea, 2010, p. 164)”.

5.2. Într-un capitol dintr-o lucrare colectivă ulterioară (RGR), același autor reia discuțiile privitoare la nonflexiunea internă a compusului altcineva din româna modernă, susținînd că altcineva și altceva „can be analyzed as compounds because this alt-is uninflected and does not appear in its regular position: direct case (NA) altcineva 'alt somebody', oblique case (GD) alt ( ${ }^{*}$ ui)cuiva" (RGR, p. 152), dar exemplele date de noi $(3,6-10,14-18,27)$ dovedesc că, în limba veche, întrebuințarea pronumelui la cazurile GD e cît se poate de firească:

(30) din spunerea și din cugetul mieu sau altuicuiva (VRC, IIIv , p. 187)

5.3. În ciuda argumentelor invocate în RGR, exemplele aduse de noi în discuție sugerează că, la început, flexiunea exista, fiind dublu marcată în cadrul sintagmei investigate, atît în ceea ce privește formele libere, cît și cele sudate. Flexiunea evidentă a celor doi termeni nu face altceva decît să ne arate că cei doi termeni sînt, în fapt pronume, altul avînd un rol de precizare. În acest sens, exemplele de mai jos sînt relevante şi putem remarca faptul că cei doi constituenți trebuie considerați pronume, existînd o serie de mărci gramaticale certe, cum ar fi desinența de masculin, desinența cazuală și marca pronominală, evidente atît la NA, cît mai ales la GD:

(30) altul cineva din crieri le-au pläzmuit, unul ca acela nici al nostru (CII, 249v p. 316)

(31) de va fi și altul cinevaş făcut ca acealea din romani (CC,IŢ R, 13 ${ }^{\mathrm{r}}, \mathrm{p} .153$ )

(32) sînt roabă Domnul mieu Isus Hristos, iară nu altuiia cuiva (Dvs, $300^{\mathrm{r}}$, p. 259)

5.4. Prin urmare, se poate observa că, din asocierea celor cuantificatori (altul, cineva), în urma unui proces de lexicalizare progresivă, a rezultat un compus (altcineva) ce face parte din clasa cuantificatorilor existențiali și care marchează „diferențierea în raport cu altă entitate din domeniul cuantificat (prin aceasta se aseamănă cu pronumele demonstrative de diferențiere), fiind corespondenți nonseparativi ai separativului altul (Altcineva vrea să-ți spună altceva.)" (GALR, I, p. 258).

5.5. Spre deosebire de alte asocieri sintagmatice ale cuantificatorilor indefiniți, constatăm că cea dintîi poziție este ocupată de altul, iar cea secundă de cineva, ceea ce ne face să presupunem că avem de-a face, în cazul lui altul, cu o topică fixă și cu specializare, care lămurește semnificația lui cineva. Pronumele altul este un adjunct cu valoare pronominală, iar nu cu valoare adjectivală cum s-ar crede la o interpretare de suprafaţă.

5.6. Fără a oferi prea multe detalii și fără a face un excurs diacronic, Van Peteghem (1999) întrevede și ea valoarea pronominală a acestui tip de constituenți în cazul limbii italiene (Chi altri/altro potrebbe farlo ? 
'Cine altcineva ar putea să o facă?'), afirmînd că „étant donné que altro a également une valeur pronominale en italien, il pourrait s'agir là d'un emploi pronominal, et non pas d'un emploi adjectival” (1999, p. 245). Același comportament sintactic îl observă și în cazul românei care se aseamănă, în această privință, cu italiana, distingînd foarte bine „la forme pronominale indéfinie altul de la forme adjectivale alt, et c'est en effet altul qui apparaît comme modificateur des pronoms intérogatifs et indéfinis” (1999, p. 245).

5.7. În ceea ce privește funcția sintactică realizată de cei doi termeni, considerăm că ne aflăm, mai degrabă, în prezența unui fenomen de dublare a funcției sintactice a lui cineva (subiect (2), complement (10) etc.), altul avînd nu numai rol de precizare, ci şi de anticipare, întocmai ca la complementul direct și la cel indirect, unde este reiterată întreaga informație gramaticală.

O dublare similară a funcției gramaticale a pronumelor nehotărîte poate fi observată și în cazul sintagmelor înrudite din limba actuală: cine altcineva și cui altcuiva, unde avem aproximativ acelaşi comportament sintactic. Nici în acest caz, nu poate fi vorba despre un acord, ci mai degrabă cu o reiterare a informației gramaticale la amîndoi constituenții, aşa cum o întrevede şi Giurgea (2010), atunci cînd discută pe marginea cazului oblic al structurii cine altcineva. Acesta consideră că „le N grammatical est épelé deux fois” și că „le mouvement du N grammatical ressemble au mouvement des clitiques, étant déterminé par un besoin de l'élément qui se déplace plutôt que de la cible” (2010, p. 166).

\section{Concluzii}

Din faptele de limbă evidențiate, reiese că procesul prin care altcineva s-a lexicalizat este unul complex și a avut loc în etape succesive, datorate, în special, unor particularități structurale. Chiar dacă modelul de realizare a fost cel oferit de limba latină, evoluția a depins, în bună măsură, de specificitatea limbii române, care s-a detaşat de limbile romanice surori, inovînd mult mai mult atît la nivel morfologic, cît și sintactic, datorită flexiunii pronunțate ce o caracterizează.

Un rol important în realizarea compusului cineva l-a avut glisarea pronumelui relativ-interogativ cine înspre sfera nehotărîtelor, odată cu atașarea particulei indefinite - va, ce caracterizează un număr semnificativ de membri.

În timp, prezența informației gramaticale în structura celor două pronume a fost simțită ca fiind greoaie, încercîndu-se concentrarea acesteia la finalul compusului. Evoluția sintagmei inițial constituite a fost una oscilantă, eliminîndu-se, într-un prim moment, desinențele de gen și caz ale alternativului, ceea ce a dus, ulterior, la sudarea compusului altcineva. Mai rezistente la compunere au fost însă formele celor două pronume la cazurile oblice, care, în timp, și-au concentrat informația gramaticală în partea finală a noului compus (altcuiva).

Considerăm că astfel de analize punctuale sînt necesare pentru înțelegerea constituirii unor părți de vorbire cu o structură complexă, deoarece ilustrează modul în care acestea au luat naștere și cum au evoluat, dar și certifică, în perspectivă sintactică, interpretarea apropriată.

\section{Bibliografie}

\section{A. Corpus}

AB = Mihail, P. \& Mihail, Z. (1993). Acte în limba română tipărite în Basarabia, vol. I (1812-1830), precedate de Bibliografia tipăriturilor românești din Basarabia (= BTRB), Editura Academiei Române, București.

AI,O = Antim Ivireanul, Opere, ediție critică și studiu introductiv de G. Ștrempel, Editura Minerva, București, 1972.

AJ = Acte judiciare din Țara Românească [1775-1781], ediție întocmită de Gh. Cronț et al., Editura Academiei Române, București, 1973.

CAM = Pseudo-Amiras, Cronica anonimă a Moldovei [1661-1729], studiu și ediție critică de D. Simionescu, Editura Academiei Române, București, 1975.

CazV. = Varlaam, Carte românească de învățătură, vol. II (Textul), ediție îngrijită și glosar de S. Toma, prefață și studiu introductiv de D. Zamfirescu, Editura Roza Vînturilor, București, 2011.

$\mathrm{CC}^{2}$ = Coresi, Cartea cu învățătură [1581], publicată de S. Pușcariu și Al. Procopovici, vol. I (Textul), Atelierele Grafice Socec \& Co., București, 1914. 
CC,IȚR = C. Cantacuzino, Istoriia Țărîi Rumânești, ediție critică, studiu filologic, studiu lingvistic, glosar și indice de nume proprii de O. Dragomir, Editura Academiei Române, București, 2006.

$\mathrm{CD}=$ D. Cantemir, Divanul sau gîlceava ințteleptului cu lumea sau Giudețul sufletului cu trupul, text stabilit, traducerea versiunii grecești, comentarii și glosar de V. Cândea, postfață și bibliografie de Al. Duțu, Editura Minerva, București, 1990.

CII = D. Cantemir, Istoria ieroglifică, ediție îngrijită de P. P. Panaitescu și I. Verdeș, Editura Minerva, București, 1973.

CLRV = Mareș, Al. (coord.) (2016). Crestomația limbii române vechi, vol. I (1521-1639), ediția a II-a revăzută și adăugită, Editura Academiei Române, București.

$\mathrm{CP}^{1}=$ Coresi, Psaltirea slavo-română [1577], in comparație cu psaltirile coresiene din 1570 și din 1589, text stabilit, introducere și indice de Stela Toma, Editura Academiei Române, București, 1976.

CPop. ${ }^{3}$ = Cele mai vechi cărți populare in literatura română, vol. III (Călătoria lui Zosim la blajini, Bertoldo), studii filologice, studii lingvistice, ediții și glosar de M. Stanciu-Istrate și M. Georgescu, Editura Minerva, București, 1999.

$\mathrm{Cv}=$ Codicele Voronețean, ediție critică, studiu filologic și studiu lingvistic de Mariana Costinescu, Editura Academiei Române, București, 1981.

Dî = Chivu, Gh., Georgescu, M., Ioniță, M., Mareș, Al. \& Roman-Moraru, Al. (eds) (1979). Documente și însemnări românești din secolul al XVI-lea, Editura Academiei Române, București.

DVs = Dosoftei, Viața și petrecerea sfinților [Iași, 1682-1686], text îngrijit, notă asupra ediției și glosar de R. Frențiu, Editura Echinox, Cluj[-Napoca], 2002.

Ê̂ = Evanghelie invaătătoare [Govora, 1642], ediție, studiu introductiv, note și glosar de A.-M. Gherman, București, Editura Academiei Române, 2011.

GS = Gromovnic (popa Stanciu, 1636), în Mareș, Al. (coord.) (2006). Cărți populare din secolele al XVI-lea - al XVIII-lea. Contribuții filologice, Fundația Națională pentru Știință și Artă, București, p. 313-320.

LRM = Mazilu, D. H. (coord.) (2003). Literatura română medievală, Editura Academiei Române \& Editura Univers Enciclopedic, București.

Mărg. = Ioan Gură de Aur, Mărgăritare, ediție îngrijită, indice de nume și glosar de R. Popescu, Editura Libra, București, 2001. MVTS = Munteanu, E. (coord.) (2016). Vechiul Testament - Septuaginta. Versiunea lui N. Spătarul-Milescu [1683-1686] (Ms. 45, BAR Cluj), Editura Universității „Alexandru Ioan Cuza”, Iaşi.

Prav.1581 = Pravila ritorului Lucaci [1581], text stabilit, studiu introductiv și indice de I. Rizescu, Editura Academiei Române, București, 1971.

Prav.1646 = Carte românească de invățătură [1646], ediție critică, ediția a fost întocmită de A. Rădulescu et al., Editura Academiei Române, București, 1961.

Prav.1652 = Îndreptarea legii [1652], ediția a fost întocmită de A. Rădulescu et al., Editura Academiei Române, București, 1962.

PS = Psaltirea scheiană comparată cu celelalte psaltiri din sec. XVI-XVII traduse din slavonește, edițiune critică de I.-A. Candrea, 2 vol., Atelierele Grafice Socec \& Co, București, 1916.

$\mathrm{SD}=$ Documente din vechiul ocol al Cîmpulungului Moldovenesc, culese, adnotate și publicate de T.V. Stefanelli, Librăriile Socec \& Co și C. Sfetea, București, 1915.

VI = Stanciu-Istrate, M. (2013). Reflexe ale medievalității europene în cultura română veche. Varlaam și Ioasaf în cea mai veche versiune a traducerii lui Udriște Năsturel, Editura Muzeului Literaturii Române, București.

VRC = Varlaam, Opere. Răspunsul impotriva catihismusului calvinesc, ediție critică, studiu filologic și studiu lingvistic de Mirela Teodorescu, Editura Minerva, București, 1984.

\section{B. Referințe}

Avram, M. (2005). Despre cîteva pronume și adverbe nehotărîte în limbile romanice, în Studii de morfologie a limbii române, Editura Academiei Române, București, p. 162-167.

Bartoli, M. (1925). Introduzione alla neolinguistica (Principi - Scopi - Metodi), Leo S. Olschki Éditeur, Genève.

Chircu, A. (2014). Observații asupra sintagmelor alt nime și nime alt în limba română veche, în Zafiu, R., Dragomirescu, A. \& Nicolae, Al. (eds), Limba română: diacronie și sincronie in studiul limbii române (Actele celui de al 13-lea Colocviu Internațional al Departamentului de lingvistică, București, 13-14 decembrie 2013), vol. I (Gramatică. Fonetică şi fonologie. Istoria limbii române, flologie), Editura Universității din București, București, p. 53-67.

Densusianu, Ov. (1961). Istoria limbii române, vol. 1 (Originile), ediție îngrijită de J. Byck, Editura Științifică, București.

Densusianu, Ov. (1962). Istoria limbii române, vol. 2 (Secolul al XVI-lea), ediție îngrijită de J. Byck, Editura Științifică, București.

Dimitrescu, Fl. (1974). Introducere in morfosintaxa istorică a limbii române, Centrul de multiplicare al Universității din București, București.

Dominte, C. (2003). Negația în limba română, Editura Fundației România de Mîine, București.

Frâncu, C. (2009). Gramatica limbii române vechi (1521-1780), Editura Demiurg, Iaşi.

GALR = Guțu-Romalo, V. (coord.) (2008). Gramatica limbii române, 2 vol., tiraj nou, revizuit, Editura Academiei Române, București.

GBLR = Pană Dindelegan, G. (coord.) (2016). Gramatica de bază a limbii române, ediția a II-a, Editura Univers Enciclopedic Gold, București. 
Gheție, I. (coord.) (1997). Istoria limbii române literare. Epoca veche (1532-1780), Editura Academiei Române, București.

Giurgea, I. (2010). Pronoms, déterminants et ellipse nominale. Une approche minimaliste, Editura Universității din București, București.

GR = Pană Dindelegan, G. (ed.) (2013). The Grammar of Romanian, Oxford University Press, Oxford.

Haspelmath, M. (1997). Indefinite Pronouns, Oxford University Press, Oxford.

Le Goffic, P. (2015). Indéfinis et interrogatifs: le cas du français, în „Langue française”, vol. 187, p. 111-136, Crossref.

Lombard, A. (1938). Une classe spéciale des termes indéfinis dans les langues romanes, în „Studia neophilologica”, vol. 11, p. 186209, Crossref.

Manoliu Manea, M. (1968). Sistematica substitutelor din limba română contemporană standard, Editura Academiei Române, București.

Manoliu Manea, M. (1993). Gramatică, pragmasemantică și discurs, Editura Litera, București.

Niculescu, Al. (1965). Individualitatea limbii române între limbile romanice, vol. I (Contribuții gramaticale), Editura Științifică, București.

Popescu-Marin, M. (coord.) (2007). Formarea cuvintelor în limba română din secolele al XVI-lea - al XVIII-lea, Editura Academiei Române, București.

Prévost, S. \& Fagard, B. (2007). Grammaticalisation et lexicalisation: la formation d'expressions complexes, în „Langue française”, vol. 156, p. 3-8, Crossref.

Pușcariu, S. (1976). Limba română, vol. I (Privire generală), prefață de G. Istrate, note, bibliografie de I. Dan, Editura Minerva, București.

REW = Meyer-Lübke, W. (2009). Romanisches Etymologisches Wörterbuch, 7. unveränderte Auflage, Universitätsverlag Winter, Heidelberg.

RGR = Dobrovie-Sorin, C. \& Giurgea, I. (eds) (2013). A Reference Grammar of Romanian, vol. I (The noun phrase), John Benjamins Publishing Company, Amsterdam-Philadelphia.

sor = Pană Dindelegan, G. (ed.) (2016). The Syntax of Old Romanian, Oxford University Press, Oxford, Crossref.

Stan, C. (2013). O sintaxă diacronică a limbii române vechi, Editura Universității din București, București.

Stoica, G. (2011). Pronumele indefinit. De la latină la româna comună, în Zafiu, R., Ușurelu, C. \& Bogdan Oprea, H. (eds), Limba română: ipostaze ale variației lingvistice, Actele celui de-al 10-lea Colocviu al Catedrei de limba română (București, 3-4 decembrie 2010), vol. I (Gramatică și fonologie. Lexic, semantică, terminologii. Istoria limbii române, dialectologie și filologie), Editura Universității din București, București, p. 443-449.

Väänänen, V. (2006). Introduction au latin vulgaire, Éditions Klincksieck, Paris.

Van Peteghem, M. (1999). L'indéfini «autre»: déterminant ou adjectif. Étude comparée français - espagnol - italien - roumain, în „Cahiers de l'Institut de Linguistique de Louvain”, vol. 25, nr. 1-2, p. 235-250, Crossref. 